\title{
IS THE PEACEFUL REGULATION OF THE NAGORNO-KARABAKH CONFLICT - MISSION POSSIBLE?
}

\author{
Natalia Bekiarova ${ }^{1}$ and Ilina Armencheva ${ }^{2}$ \\ ${ }^{1}$ Prof. Ph.D., National Defense College, Sofia, Bulgaria, nataliab@abv.bg \\ ${ }^{2}$ Associate professor Ph.D., National Defense College, Sofia, Bulgaria, ilina_arm@abv.bg
}

\begin{abstract}
The conflict between Armenia and Azerbaijan for Nagorno-Karabakh is one of the most difficult to solve from all existing "frozen" conflicts. The knot of many problems interweaves historical burden and modern reality, occupied territories, military successes and defeats, tens of thousands killed, the fate of over one million refugees and forced evicted citizens, and a combination of Rivalry, interests and ambitions of the big international players. Almost 30 years since the beginning of the conflict and a quarter of a century of attempts for its peaceful and sustainable regulation by the OSCE Minsk Group, there is still no any progress towards its resolution. This article gives an overview of the options available to the conflict and the reasons for the lack of a solution acceptable to both parties. It also presents the current state of the conflict regulation processes and the positions of the States involved in the conflict. It is recalled the famous maxim that success in politics depends on achieving a balance between the interests of equally "unhappy" countries.
\end{abstract}

The authors share their expert point of view on the need for compromises and acceptable concessions from Armenia and Azerbaijan, the role of Russia, the USA and France, as co-chairmen of the Minsk Group, as well as and active involvement of the wider international community for a peaceful, equitable and legal resolution of the conflict.

The publication forecasts the future status of the relations between Armenia and Azerbaijan. The focus is on the new aspects in the politics of Baku and Yerevan after the last big escalation of April 2016. The current policy of the major countries involved in the conflict are clarified. Opportunities for sustainable conflict resolution are presented.

Keywords: conflict, negotiation process, OSCE Minsk Group.

\section{INTRODUCTION}

The Nagorno-Karabakh conflict that began in February 1988 and pitted against each other Armenia and Azerbaijan is amongst the bloodiest and most complex of all interethnic conflicts that marked the dissolution of the USSR. In the history of the Soviet nations no other armed ethnic conflict can match its brutal violence, nor the lasting demographic, territorial and ethnopolitical changes that it brought. It is correct to state that the conflict has cast profound doubt in the principles and the vitality of the USSR national policy as well as in the future of the "perestroika" in the final days of the Soviet political model. What started as a mere testament to the failure of the Soviet national policy on regional and peripheral level, escalated into an interethnic war which discredited the USSR and contributed to its dissolution. Karabakh is the first interethnic conflict and it 
shook thoroughly the whole party and power apparatus of the Union and ultimately became the harbinger of its demise (Markedonov, 2013a).

The formal ground for the conflict was the fact that the Armenian delegates to the Nagorno-Karabakh Autonomous Oblast's Regional council voted on the 20th of February 1988 on the secession of the territory from the Azeri SSR and on its unification with the Armenian SSR. The reasons for this act, however, remain various and multi-sided. Moscow's total control over the Soviet periphery weakened significantly during Gorbachev's tenure; both sides interpreted frivolously their own history claiming that Karabakh constituted an integral part of their "glorious" past. The Muslim-Christian antagonism between the Armenian (Christian) and the Azeri (Muslim) parts of the populace; the differing cultures and national psychology over the course of the centuries resulted in an everlasting animosity. All these factors are exacerbated by the struggle for influence over the South Caucasus which does include various international actors as well.

The fighting/active military operations went on for almost six years (1988-1994). The period can be divided in two by the terminal dissolution of the USSR and the declarations of independence of both belligerent states: Armenia and Azerbaijan. 1991 saw the declaration of independence of the Nagorno-Karabakh republic. The second phase of the conflict (1992-1994) was markedly bloody and saw the escalation of the hostilities into a full-fledged war. Between the 30th of April and the 12th of November 1993 the UN Security Council adopted four resolutions 822, 853, 874 and 884, which failed to bring the fighting between Armenia and the nonrecognized Nagorno-Karabakh republic, on one side, and Azerbaijan, on the other, to an end. By the spring of 1994 both sides were facing insurmountable personnel and materiel losses and recognized the need to stop the hostilities. The active efforts of Moscow, the UN resolutions and the decisions of the OSCE bore fruit on the 5th of May 1994 when in Bishkek, the capital of Kyrgyzstan, an armistice was signed between the representatives of Armenia, Azerbaijan and the unrecognized Nagorno-Karabakh republic. The ceasefire came into force at midnight of the 17th of May 1994 which essentially led to the freezing of the conflict which continues as of today. Formally, the Armenian armed forces won the military conflict, but it is still not officially over due to the lack of a peace treaty.

The armistice that was signed was not abided by. Fire across the border between Azerbaijan and the breakaway region of Nagorno-Karabakh is a regular occurrence that threatens to reinstate the conflict. In fact violating the ceasefire is more of a rule than an exception. Both sides regularly employ machine guns and mortars in the clashes. Each incident sees Baku and Stepanakert blaming each other for the provocation. What's more, the number of the casualties rises steadily and prisoners of war are often taken.

The most notable flare-up of the conflict was the so called 4 day war that began on the 2 nd of April 2016. It marked the first time that the clashes engulfed the whole frontline as well as the first use of all equipment that both sides had in their arsenal - artillery, armored vehicles, aviation. The end of the hostilities did not break the well established rhythm of the conflict which continues to today: escalation, temporary placation followed by a new cycle of escalation.

\section{THE CONSEQUENCES OF THE CONFLICT}

The Karabakh problem, understood in modern political sense as a conflict between Azerbaijan, on one hand, and Armenia and the Nagorno-Karabakh republic, on the other, is extremely complex. The reasons for such complexity are multi-layered. Firstly, one has to take into account the changed borders of all participating actors. As a result of the hostilities the breakaway republic of Nagorno-Karabakh controls more than $80 \%$ of the former Azeri Nagorno-Karabakh Autonomous region. What's more, the Armenians have completely occupied five regions of Azerbaijan and partly control two more. The Nagorno Karabakh forces currently fully hold the Kelbajar, Lachin, Kubatlin, Jabrail, Zangezur districts and up to $30 \%$ of the Agdam and Fisulin districts (Bekiarova, 2012a).

On the other hand, Azeri armed forces control two northern districts of the former Nagorno-Karabakh autonomous region spanning 750 square kilometres: 630 square $\mathrm{kms}$ in the Shaumyanovski district and pockets of the Martunin and Martakert districts. The conflict map changed once again in April 2016 as the Azeri army recaptured some territory that was held until then by the Karabakh forces.

The situation is even further complicated by the fact that the Azeri armed forces have exercised control over an Armenian enclave in Azerbaijan since 1992. The 50 square kilometer Artsvashen enclave is internationally recognized as being an integral part of the Republic of Armenia (Artsvashen, 2014a).

All the occupied regions that are outside the Nagorno-Karabakh republic have been declared "security zone" and the local population has been forced out. The once thriving communities are now barren. They have become ghost towns, testament to the futility and cruelty of the war. The fact that the Armenians have conquered such vast swathes of Azeri territory despite their limited demographic and military potential makes 
them feel victorious.

Up until the beginning of the conflict, Karabakh was an Armenian ethnic enclave inside Azerbaijan. Its population stood at about 189000 people of which nearly 145000 (76,9\%) Armenians and the region spanned $4400 \mathrm{sq} \mathrm{kms}$. Based on data provided by the Armenian side, currently the breakaway republic controls $11500 \mathrm{sq} \mathrm{kms}$ including the security zones and has a population of 137737 people (Nikiforov, 2018a). Presently, the Nagorno-Karabakh republic has a vast land border with Armenia. However, the access and free flow between Azerbaijan and its exclave Nakhichevan is possible only passing through the territory of neighboring Iran.

The Armenian side firmly insists that the territories held by the Nagorno-Karabakh forces historically belong to the Armenian Artsakh (the Armenian name for Karabakh) as well as it claims that the Azeri troops have illegally occupied the two northern districts which too do belong to the breakaway state. On the other hand Baku is of the opinion that the Armenians have violated the principles of international law and rule over territories that are inseparably part of the state of Azerbaijan. Each side views itself as a victim of the other's aggression and calls for justice, which it interprets according to its own interests.

Along with the border changes, the Karabakh conflict has led to a complete border blockade. Both states closed their respective borders once the conflict erupted. Solidarity with Azerbaijan has lead Turkey to close its border with Armenia in 1993. Yerevan has imposed countermeasures which practically left Nakhichevan totally blocked and isolated, which has caused severe economical, transport and political issues for both sides.

The number of casualties and refugees is immense. There are serious discrepancies in the statistical data regarding their tally depending on whether Baku, Yerevan or Stepanakert does the calculation of the casualties, the refugees and the internally displaced persons. The number of people who perished in the conflict is between 25000 and 35000 . The refugee and internally displaced persons count however is several times higher. Baku claims that more than a million Azeris have left Armenia, Karabakh and the rest of the occupied Azeri districts (2009a). The Armenians who have left Azerbaijan and those who fled Karabakh number around 360000 (2004a). The data is highly controversial, but regardless what the exact numbers are, it should be emphasized that hundreds of thousands of people are still awaiting a just resolution to their problems. They demand on being indemnified for their miserable refugee life, notwithstanding whether they fled to Armenia, Karabakh or Azerbaijan. Their expectations are first and foremost tied to their right to work, to the receipt of valid IDs, to their homes and to a compensation for all their suffering. It must be noted that as the Nagorno-Karabakh republic lacks international recognition, some of the refugees are not able to obtain valid asylum status.

An important effect of the war is the abysmal standard of living of the general population in the three countries. In all three of them it is lower compared to the pre-war data. This holds especially true for the Nagorno-Karabakh republic, where as per unofficial sources, the GDP per capita is equal to $\$ 3000$ (Nikiforov, 2018a). This effectively means that the population of the breakaway region is even poorer than poor Third world countries. Poverty is rampant in Armenia as well as demonstrated by the statistics, which show a GDP per capita of $\$ 9,500$ (Armenia, 2018b). Azerbaijan is an outlier in the sense that its hydrocarbon fossil fuel reserves are considerable, which makes it markedly richer. Thus for 2017 it boasts a per capita GDP of $\$ 17,500$ (Azerbaijan, 2018c). However this does not translate to a generally wealthier population as poverty is widespread and the inequality is staggering.

A significant reason for the actual state of the conflict is the public sentiment in Armenia, Nagorno-Karabakh and Azerbaijan. The roots for all actions carried out by both sides stem from pain, hate and the bloodshed, emotions which would hardly be placated no matter what treaties, pacts or documents are signed. The people in both Armenia and Azerbaijan are still recuperating from the grisly war. The public sentiment clearly demonstrates the lack of will for concessions or for a treaty that accomplishes anything that but the maximum desired outcome, a fact which clearly shows the resilience of the conflict.

The goal for the Armenian population is the creation of an independent Nagorno-Karabakh state, while Azerbaijan wishes to achieve the irrevocable return of Karabakh and the rest of the occupied territories under its control.

The political forces in both Armenia and Karabakh, the general sentiment in the Parliament and in the Government, amongst the intelligentsia and the military, in the media, as well as the aspirations and the wishes of the general populace are marked by their intransigence. The destiny of Nagorno-Karabakh is believed to be only the one of either an independent state or of an integral part of Armenia. The ruling class of Armenia has completely discarded any notion of vertical subordination between Stepanakert and Baku. Understandably, the nationalistic rhetoric is revitalized with every election cycle. The complex socio-political 
and economical issues are pushed to the side by the slogans for a "just" solution to the conflict.

The situation in Azerbaijan is not at all different. Baku insists on a gradual solution to the conflict while abiding by the principles of the territorial integrity of the Azeri state and the return of control of the currently occupied districts. Another point that the Azeri side makes is the unequivocal return of the forcefully displaced persons and refugees to their homes and having certainty regarding their safety. Baku does concede that Nagorno-Karabakh might receive the right to autonomous home rule, while maintaining sovereignty over the region. It is generally accepted that should the Azeri side not be able to resolve the conflict peacefully in accordance to the UN Charter, then it should proceed and through the use of force regain control of the lost territories and vanquish the Armenian aggressor. The atmosphere of irreconcilability persevered from the very beginning of the conflict to present day while showing significant resilience.

Since the freezing of the conflict, the most dynamic changes in the last quarter of a century have been in both sides' armed forces. The azerbaijani army has around 67000 people in active service and its budget for 2016 was $\$ 1.74$ billion. According to the most relevant data, Armenia counts with 51000 people in its armed forces and Nagorno-Karabakh has mustered an 18000 to 20000 -strong army. Compared to Baku's, Armenia's military budget is $\$ 430$ million (2017a).

Azerbaijan is quickly modernizing its army and procuring modern weaponry from Turkey, Israel, Russia and other countries. The military parade that celebrated the centenary of the Azerbaijani army on the 26th of June 2018 displayed the new weaponry that it had. It featured the SOM-1B cruise missiles, the new Russian T-90C tanks, BMP-3, the BTE-82A APC and other pieces of Russian equipment. The Israeli products that were present were Hermes-900, Hermes- 450 and Heron as well as Cardom mortars, Barak-8 SAM launchers, Lynx multiple rocket launchers and Lora theater missile launchers. Baku has acquired Bell 412 multipurpose helicopters as well (Zhelev, 2017b).

Compared to the Azeri army, the Armenian one boasts an older and humbler set of equipment. The Armenian armed forces, respectively the Karabakh forces as well, employ WM-80 multiple rocket launchers. Currently they have $8273 \mathrm{~mm}$ WM-80 launchers that were made in China. The missiles' maximum range is between 80 and $120 \mathrm{~km}$. The launchers were acquired in the '90s. Over the course of the following years new missiles with bigger ranges as well as 9K72 Elbrus launchers, NATO denomination Scud-B, were procured. Karabakh's armed forces posses 9P117M/R-300 launchers and at least 32 R-17 missiles. The missiles were acquired from the arsenal of the 176th Armenian Missile Brigade, part of the 7th Armenian army, as a part of a '90s Soviet military equipment sharing treaty. The R-17 missiles have a $300 \mathrm{~km}$ maximum range with accuracy up to $0,6 \mathrm{~km}$. 2011 saw the purchase of Uragan missiles from Moldova. Yerevan employs Smerch launchers as well. Said Smerch launchers are used by Baku too, which purchased them from Ukraine in 2004-2005. Both states employ tactical Tochka-U missiles with maximum range up to $120 \mathrm{~km}$ (Zhelev, 2017c).

The military equipment that both sides possess indicates an intention to deter, not one to wage war. Both countries count chiefly with tactical and short range missiles and with multiple-rocket launchers. Irrespective of the missiles in the Azeri arsenal, the country's territory is highly vulnerable from a military point of view. The Karabakh forces can carry out strikes against crucial energy transmission infrastructure and power grids, against communication networks and critical industrial facilities. Such vulnerability is the reason why the Azeri side abstains from further actions. An Azeri response strike would not damage significant infrastructural or industrial objects inside Karabakh. Another deterrent is the fact that Armenia is part of the Collective Security Treaty Organization. Just like the Warsaw Pact and NATO, the participants in the organization rely on the aid of the other member states. This would effectively mean that Russia, Belarus, Kazakhstan, Kyrgyzstan and Tajikistan are all to join the fray on Armenia's side. Therefore, the use of force is to be discarded as a means of resolving the Karabakh conflict. 


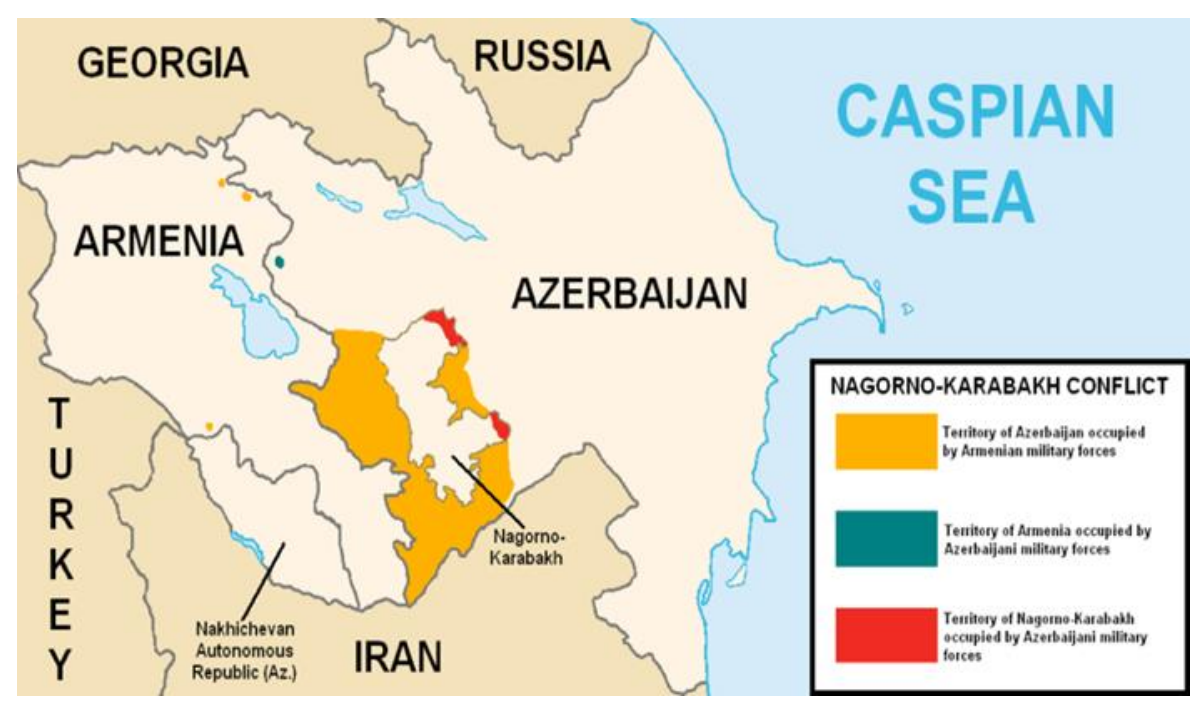

Fig.1. Nagorno-Karabakh conflict

\section{IN SEARCH OF A PEACEFUL SOLUTION}

So far, attempts to resolve the conflict have shown that Armenia and Azerbaijan are not able to reach an agreement by themselves. One of the reasons is not only the distinction in their principle position, but the "over-exploitation" of the Karabakh drama for various internal political struggles and the distribution of power, because the resolution of the conflict in "their favour" has long become the prime target of all those bound for a political career.

The efforts through external interference to influence the conflict regulation also fail. The reasons therefore are many. The most important one is the fact that both large and regional geopolitical players have mixed interests and views about the outcome of the conflict. These are primarily Russia, USA, Iran, Turkey and the European Union. Until now, practice shows that none of them has the capacity, desire or the necessary political influence to do it on its own. Because of this, solutions are primarily sought through the Organization for Security and Cooperation in Europe. Since 1992 up to now, resolving the conflict has been primarily the work of the OSCE Minsk Group. During the existence of the USSR, no international negotiations have been conducted. They became possible in 1992 after Armenia and Azerbaijan had become sovereign states. The Helsinki Summit meeting on 24 March 1992 on Security and Cooperation in Europe brought together a conference on the problems of Nagorno-Karabakh with the participation of Armenia, Azerbaijan, Belarus, the Czech Republic and Slovakia, France, Germany, Italy, Russia, Sweden, Turkey and USA. The main objective has been to end the fire and negotiate the status of Karabakh. On Belarus's proposal, the capital Minsk was designated as the venue for negotiations. This is how the entire negotiation process got it's name, even though the decision had been changed and the meetings had started in Rome. Vain attempts have been made to send multinational peacekeeping forces to support peace and stability in Karabakh, and since 1997, representatives of Russia, France and the United States have been appointed as permanent co-chairs of the Minsk Group (2018d).

The attempt to regulate the conflict at the OSCE Lisbon Summit in 1996 is of historic importance because it formulates the first international positions of principle regarding its resolution. Shortly thereafter, at the 15th session of the OSCE Ministerial Council on 29 and 30 November 2007, the so-called "Madrid document" was adopted. It contains the basic principles for resolving the conflict. These principles are not officially published in their original form, making it difficult for statement and interpretation. In addition, the statements evolve and change over the coming years. Among the most important requirements that are being sustained are the need for gradual withdrawal of all Armenian forces from all the occupied territories of Azerbaijan; guaranteeing free movement along the Lachin Corridor between Nagorno-Karabakh and Armenia, as well as free movement through Armenia to the Azerbaijan province Nakhichevan. Another essential requirement is guarantying the right to voluntary return of all refugees and internally displaced persons; creating a transitional status of the Nagorno-Karabakh self-government, while creating the necessary conditions for an honest referendum to determine the final status of the area, and so on (2009b). Although these principles are widely publicized, they do not lead to the resolution of the conflict. There is also some contradiction in the positions because it is difficult to bring together the principles regarding the release of the occupied Azerbaijani territories and the holding of a referendum on the status of Nagorno-Karabakh. 
New hope gave the summit of presidents of Russia, Armenia and Azerbaijan in the autumn of 2008 in Moscow. On November 2, 2008, in Mayendorf Castle, under the patronage of Russian President Dmitry Medvedev, the presidents of the two warring parties, Ilham Aliyev and Serge Sargsian, signed a declaration, which was the first common document after the ceasefire in 1994 (2008a). The Mayendor Declaration, consisting of five main points, states that "contribute to a healthier situation in the South Caucasus and the establishment of regional stability and security through a political settlement of the Nagorno-Karabakh conflict on the basis of the principles and norms of international law." Thus the violent, military means are ignored, which at least means that the sharpness of military threats will decrease. The second point of the declaration confirms the importance of the efforts of the OSCE Minsk Group and of the proposed principles during the Madrid meeting to become a basis for discussion in order to further work on the political regulation of the conflict. On the third point of the declaration, the Presidents of Armenia and Azerbaijan accept that peace regulation must be accompanied by legally binding international safeguards on all aspects and stages of work. At the fourth point, presidents Ilham Aliyev and Serge Sargsian agree to continue their work at the highest level and step up the next steps in the negotiating process, together with the co-chairs of the Minsk Group. This means that its format will remain the same as at that time neighboring countries Turkey and Iran have shown serious demands for participation in the work group.

The last part of the agreement refers to the "need to promote confidence-building measures in the context of peaceful regulation"(2008a). Behind this diplomatic language lies intentions rather than the pursuit of real action. Meanwhile, the Maidenhead Declaration once again showed that without Russia, it is difficult to resolve any political issue in the South Caucasus. In addition, the document played the part of a PR action for Kremlin, who strongly needed to show a changed political image after the war in Georgia in August 2008. This result is proven in the following years when, in addition to the regular meetings between the three presidents under the auspices of Dmitry Medvedev, nothing significant has been achieved. So the status quo "neither peace nor war" is preserved for long.

On 10 July 2009, the G8 summit, Barack Obama, Dmitry Medvedev and Nicolas Sarkozy (the countries cochairing the Minsk process), adopted a new declaration on the Nagorno-Karabakh conflict. It once again reaffirmed their duty to assist the Baku and Yerevan authorities in agreeing on the basic principles of conflict regulation. They have been provided with an updated version of the Madrid 2007 Document containing the latest revision of the known principles. It appears that the conflict would be resolved in the near future. Instead, however, the last two meetings between Armenian and Azerbaijani presidents, in Kazan in 2011, and in Sochi in 2012, mediated by Russian President Medvedev, have once again proved fruitless. Azerbaijan's official stance that the conflict, which began in 1988, is the result of Armenian military aggression in order to tear down territories from Azerbaijan and join the borders of Armenia. The main views of Azerbaijani politicians are focused on the understanding that the territory of Azerbaijan is in a regime of occupation, ethnic cleansing over the country's population has resulted in the slaughter of the NagornoKarabakh territory and other occupied seven regions hundreds of thousands of Azerbaijan expelled. Based on the many prestigious international documents, including the UN Security Council resolutions, decisions at the OSCE Summit in Lisbon, and on the basis of the principles of international law, it has been demanded for the release of occupied territories by the Nagorno-Karabakh Army (2018e).

After a long break in the negotiation process, in December 2015, in Bern, Armenia and Azerbaijan resumed the dialogue, but unfortunately both countries demonstrate their adherence to their old positions. This is the reason for a new pause and resumption of the negotiations in Geneva in October 2017. The new meeting of Presidents Alejiv and Sarkisian. Foreign Affairs Ministers Meetings, Lavrov's visit to Yerevan and Baku and others.

Baku's diplomacy firmly defends its own opinion that the conflict can be resolved within the territorial integrity of Azerbaijan, and this position has no other alternatives. Referring to the Charter of the United Nations and OSCE, Azerbaijan calls for the restoration of its territorial integrity. According to Azerbaijan diplomacy, the peaceful resolution of the Nagorno-Karabakh conflict is not limited to the return of the seven regions around Nagorno-Karabakh. The main objective is to fully restore the territorial integrity of the country and to grant appropriate status to Nagorno-Karabakh within Azerbaijan.

The consideration of the cardinal principle in modern international law on the right of peoples to selfdetermination and detachment, calls for the achievement of this right only within the territorial integrity of Azerbaijan. The status of Nagorno-Karabakh is to be determined once the Azerbaijani population has returned in the area, while at the same time guaranteeing security of both the Azerbaijani and the Armenians. Only then those negotiations to determine the final status of Karabakh are possible. Regarding the road passing through the Lachine Corridor, the proposal is that it is to be used by both parties, which will allow for the normal, secure and permanent functioning of the transport systems. 
Armenia's official position on the Karabakh issue is based on the native law of self-determination of nations (2018f). It insists on the fact that Nagorno-Karabakh has already been built and functions as a state, and the population of this unrecognized state has the right, through a referendum, to once again declare its strong desire to develop its sovereignty and statehood. Although Armenia itself has not recognized the autonomous existence and sovereignty of the Nagorno-Karabakh republic, it is argued whenever there is an opportunity that Karabakh has the right to freedom of expression because it has proved its right to be a state.

The Armenian side accepts the understanding that Azerbaijani refugees can and should return to their homes. However, this can only happen after a referendum to determine the future status of the area. Baku's diplomacy insists that representatives of Nagorno-Karabakh are to be included in the negotiation process as an opportunity to find an acceptable solution to the conflict.

Armenian diplomacy praised the expert work of OSCE Minsk group politicians and says Yerevan considers it inappropriate to involve other actors and entities in the peace process. Special attention is paid to peaceful means and compromises as the only option for durable solutions. It is insisted that the NKR should also be involved in the decision-making process. He underlined the ideology that all the decisions to be made to regulate the conflict must be in line with the realities and the actual existence of Nagorno-Karabakh, which besides its own country should maintain its territorial link with its homeland - Armenia.

The Armenian authorities' formula "territory against status", aims to force Azerbaijan to waive it's claims on Nagorno-Karabakh against the surrender of the Azerbaijan-occupied territories from the "security zone." This formula, the Azerbaijani side regards as "territories against independence," as Yerevan's attempt to redeem it's military victory in the conflict and expand the territory of Armenia (2015a). Various approaches to resolving the conflict, including bundled solutions, phased resolution of controversial issues and integration approach, have also been commented on.

Meanwhile, the scientific and political thinking of Armenia and Azerbaijan, of many international experts, abounds in ideas. They see opportunities to solve the Karabakh conflict in different options and variations. The ideology of external coercion, the Dayton model or integrated governance of Nagorno-Karabakh with the involvement of UN forces; transitional status for Nagorno-Karabakh until full agreement of key decisions is reached between interested parties; broad autonomy for Nagorno-Karabakh, but without the recognition of an independent state, are all being considered. There are also number of other approaches to reach the extreme options: exchange of territories between the two warring states; the formation of an associated state between Azerbaijan and Karabakh; Nagorno-Karabakh to become part of the Republic of Armenia; the implementation of the Cyprus model; federal model of statehood in the South Caucasus of the Caucasian Benelux type; Andorian version and many more (Abasov, Khachatrian, 2002a). The most pessimistic scenario - a new war between Armenia and Azerbaijan - and the decisive victory of one of the countries - is not entirely excluded. However, the positions of Armenia and Azerbaijan remain diametrically opposed, and it is difficult to find an acceptable common ground. The behavior of Armenian and Azerbaijani diplomacy is reminiscent of a mirror image because both countries do not give up. In fact, the efforts of the Minnesian group began to resemble the attempts of those shamans who treat severe diseases only with spells.

\section{POSITIVE SIGNS}

Often, the status quo "neither peace nor war" seems unshakable. In recent years, however, encouraging, positive signs have been lurking. Above all, a "velvet revolution" took place in Armenia, and the democratic forces of Nicole Pashinian are in power. In May 2018, he held the post of an acting prime minister, and in the early parliamentary elections held on 9 December 2018, his bloc won $70.43 \%$ of the vote, which is a sure sign of deepening democratic change (2018g). He takes a firm standl in the country's priority issues, where he wants Armenia to establish a direct relationship with Turkey without preconditions (2018h). Such a step will positively affect the resolution of the Karabakh drama. Ambitions are being demonstrated to speed up the negotiation process and to resolve the conflict peacefully for Karabakh. There have already been open talks of compromises and concessions, but it is insisted on the recognition of the Karabakh's people right to self-determination. According to Pushinian, the people of Karabakh have to choose their own future. It is not possible for Azerbaijan to return only the territory of the area without the population. That would mean a new genocide over the Armenians. The people of Karabakh have the sacred right to live freely and securely in their homeland (2018i).

The position of the official authorities of the two warring states about the necessity of new measures to strengthen confidence and the non-use of force is constructive and in the interest of a peaceful resolution of the Karabakh issue. Additional measures are being initiated to reduce tension on the front line and investigate incidents (2017d).

It is therefore encouraging that a new round of talks are expected. At the end of the Commonwealth of 
Independent States Summit in Dushanbe on 28 September 2018, a meeting was held between Azerbaijani President Ilham Aliyev and Armenian Prime Minister Nicholas Pashinian. This was their first meeting after the political change in Yerevan. Immediately there was an eased tension on the front line and this was a good sign to be developed and strengthened.

Reference is made in this respect to the findings of the OSCE Ministerial Council Meeting in Milan, the CoPresidents of the OSCE Minsk Group and Azerbaijan Foreign Minister Elmar Mamdadjarov and the acting Foreign Minister of Armenia, Zoharb Munchusanian, concluded on 6.12.2018. They agree to continue their work on a just and lasting peaceful settlement of the Nagorno-Karabakh conflict (2018j). The foreign ministers of Armenia and Azerbaijan are due to meet in early 2019 and, together with Minsk Group CoChairs, to discuss and prepare the new high-level negotiations. The positive point of view here is that, unlike many other international issues where Russia and the West have deeply different positions, in the case of the regulation of the Karabakh conflict there is a full consensus between Russia, the US and France. This is one of the serious constraints for both Baku and Yerevan.

Conflict resolution is a possible mission. Without unnecessary enthusiasm and overrated expectations, it is important to give way to pragmatism, common sense and compromise. Along with new the people involved, a rethinking of the positions is possible. The reputation of either party will not be damaged if reasonable compromises and symmetrical concessions are allowed. Obviously, the continuation of the conflict reflects extremely negatively on both the lives of people in Nagorno-Karabakh and the populations of Armenia and Azerbaijan. Continuing shootouts and mutual killings on the front line alone keep alive the hatred and tension between the two peoples. The beginning of conflict resolution should be sought in a unified approach to the problems of Armenia, Azerbaijan and the unrecognized Nagorno-Karabakh republic, as well as in the finding of working, compromise formulas. Decisions can only happen when psychological barriers are overcome, and mutual attacks mitigated and the views, arguments and interests of each party are respected. However, the prudent policy is not always the real policy (Terziev, Petkov, Krastev, 2018k-t; Petkov, 2018u).

\section{CONCLUSION}

At present, maintaining the status quo and the stability does not seem to have any other alternative. Whatever future decisions the political practice present, the mandatory conditions are that changes take place without the use of force and the preservation of the agreed negotiating format. This is in the interest of the conflict parties, the other countries in the region and the great powers. Most likely, the status quo will remain in the foreseeable future.

It should also be taken, that more than 30 years since the beginning of the conflict, many things, both in the geopolitical reality and in the lives of societies, have been profoundly changed, and the adherence to "maximum plans" is not in the public interest. It is time to test the wise thought that success in politics can only be achieved when a balance is struck between the interests of equally unhappy parties. In such a conflict like the one in Karabakh, a party couldn't possibly "beat" the other, and leave it harmed. This will not resolve the conflict, but it will further deepen it. The only way to succeed is in peaceful negotiations, without saber-rattling and threat of use of power, reasonable and liable compromises that do not harm the parties' "vital interests". It is appropriate to extend the involvement of civil society in the processes of peaceful regulation, etc. popular diplomacy to enable the two nations to gradually rebuild their trust and help resolve the conflict. The use of "soft power" instruments, political and diplomatic steps is a good start to the long road to peace.

\section{REFERENCE LIST}

Markedonov, Sergey. (2013a). The Cold War Legacy in Nagorno-Karabakh: Visions from Russia, the United States and Regional Actors. Europe's Next Avoidable War: Nagorno-Karabakh, eds Michael Kambeck and Sargis Ghazaryan. Basingstoke: Palgrave Macmillan, p.133.

Bekiarova, Natalia. (2012a). Vŭzmozhna li e nova voĭna mezhdu Azerbaĭdzhan i Armeniya za Nagorni Karabakh? Godishnik na Voenna akademiya „G.S.Rakovski“, Sofiya, s.138-139;

Artsvashen. (2014a). Otorvannyy ot karty ostrovok. http://www.yerkir.am/ru/news/view/66022.html.

Nikiforov, Vladislav. (2018a). Karabakhskiy konflikt vkrattse: sut' voyny i novosti s fronta. https://militaryarms.ru/geopolitika/karabaxskij-konflikt/. 
The results of Armenian aggression. (2009a). http://supremecourt.gov.az/en/static/view/169.

Some 65,000 refugees from Azerbaijan gain Armenian citizenship. (2004a). https://www.unhcr.org/news/latest/2004/2/40239bba4/65000-refugees-azerbaijan-gain-armeniancitizenship.html.

Armenia. (2018b). https://www.cia.gov/library/publications/the-world-factbook/geos/am.html.

Azerbaijan. (2018c) https://www.cia.gov/library/publications/the-world-factbook/geos/aj.html.

Number and Armaments of the Armed Forces of Armenia and Azerbaijan. (2017a). https://www.Iragir.am/en/2017/08/29/37373.

Zhelev, Zhivko. (2017b). Informatsionni operatsii i informatsionno vŭzdeǐstvie, „G.S.Rakovski“, Sofiya, s.57.

Zhelev, Zhivko. (2017c). Tekhnologiya na vŭzděstvieto v sŭvremennata informatsionna sreda. sb.Sŭvremenni predizvikatelstva pred sigurnostta i otbranata. Chast vtora, Sofiya, „G.S.Rakovski", s.220.

Who we are? (2018d). https://www.osce.org/minsk-group/108306.

Statement by the OSCE Minsk Group Co-Chair countries. (2009b). https://www.osce.org/mg/51152.

Armenia, Azerbaijan Sign Joint Declaration Over Nagorno-Karabakh. (2008a). https://www.rferl.org/a/Kremlin_Hosts_Peace_Talks_Over_NagornoKarabakh/1337420.

Aggression of Armenia against Azerbaijan. (2018e). http://mfa.gov.az/content/816.

Nagorno-Karabakh issue. (2018f). https://www.mfa.am/en/nagorno-karabakh-issue

The Nagorno-Karabakh conflict between Armenia and Azerbaijan: An overview of the current situation. (2015a). https://europeanmovement.eu/wp-content/uploads/2015/05/2013.09-Current-situationNagorno-Karabakh.pdf.

Abasov, A., Khachatrian, H. (2002a). Variants for a Solution of the Karabakh Conflict: Concepts and Reality. AREAT, p.5-88.

Armenia election: PM Nikol Pashinyan wins by landslide. (2018g). https://www.bbc.com/news/world-europe46502681.

Armenia ready to establish relations with Turkey but without preliminary conditions. (2018h). http://tass.com/world/1035320.

Prime Minister Nikol Pashinyan delivers speech at UN General Assembly. (2018i). http://www.primeminister.am/en/press-release/item/2018/09/26/Nikol-Pashinyan-speech/.

Statement by the European Union at the 1163rd meeting of the OSCE Permanent Council. (2017d). https://www.osce.org/permanent-council/356551?download=true.

Joint Statement by the Heads of Delegation of the OSCE Minsk Group Co-Chair Countries, Armenia, and Azerbaijan. (2018j).

ww.mid.ru/en/foreign_policy/news//asset_publisher/cKNonkJE02Bw/content/id/3436710.

Terziev, V., Petkov, M., Krastev, D. (2018k). Operative mode for police cooperation between the member states of the European Union. // Proceedings of SOCIOINT 2018- 5th International Conference on Education, Social Sciences and Humanities, 2-4 July 2018- Dubai, U.A.E, International Organization Center of Academic Research, www.ocerints.org, pp.473-476, ISBN: 978-605-82433-3-0.

Terziev, V., Petkov, M., Krastev, D. (2018I). European arrest warrant: appearance and preferences for fulfillment. // Proceedings of SOCIOINT 2018- 5th International Conference on Education, Social Sciences and Humanities, 2-4 July 2018- Dubai, U.A.E, International Organization Center of Academic Research, www.ocerints.org, pp. 477-481, ISBN: 978-605-82433-3-0.

Terziev, V., Petkov, M., Krastev, D. (2018m). Eurojust casework on mafia-type criminal organisations. // Proceedings of SOCIOINT 2018- 5th International Conference on Education, Social Sciences and Humanities, 2-4 July 2018- Dubai, U.A.E, International Organization Center of Academic Research, www.ocerints.org, pp.487-491, ISBN: 978-605-82433-3-0.

Terziev, V., Petkov, M., Krastev, D. (2018n). Concept of joint investigation teams. // Proceedings of SOCIOINT 2018- 5th International Conference on Education, Social Sciences and Humanities, 2-4 
July 2018- Dubai, U.A.E, International Organization Center of Academic Research, www.ocerints.org, pp.492-496, ISBN: 978-605-82433-3-0.

Terziev, V., Petkov, M., Krastev, D. (20180). European arrest warrant and human rights of the accused. // Proceedings of SOCIOINT 2018- 5th International Conference on Education, Social Sciences and Humanities, 2-4 July 2018- Dubai, U.A.E, International Organization Center of Academic Research, www.ocerints.org, pp.501-504, ISBN: 978-605-82433-3-0.

Terziev, V., Petkov, M., Krastev, D. (2018p). Pumps for the action on the European Union in the scope of the European agenda on security. // Proceedings of SOCIOINT 2018-5th International Conference on Education, Social Sciences and Humanities, 2-4 July 2018- Dubai, U.A.E, International Organization Center of Academic Research, www.ocerints.org, pp.497- 500, ISBN: 978-605-82433-3-0.

Terziev, V., Petkov, M., Krastev, D. (2018q). The process of forming a criminal policy of the European Union. // Proceedings of SOCIOINT 2018- 5th International Conference on Education, Social Sciences and Humanities, 2-4 July 2018- Dubai, U.A.E, International Organization Center of Academic Research, www.ocerints.org, pp.505-510, ISBN: 978-605-82433-3-0.

Terziev, V., Petkov, M., Krastev, D. (2018r). Organization on the European Union in the sphere of penal preparation. // Proceedings of SOCIOINT 2018- 5th International Conference on Education, Social Sciences and Humanities, 2-4 July 2018- Dubai, U.A.E, International Organization Center of Academic Research, www.ocerints.org, pp.482-486, ISBN: 978-605-82433-3-0.

Terziev, V., Petkov, M., Krastev, D. (2018s). Sources of European Union law. // Proceedings of SOCIOINT 2018- 5th International Conference on Education, Social Sciences and Humanities, 2-4 July 2018Dubai, U.A.E, International Organization Center of Academic Research, www.ocerints.org, pp.511516, ISBN: 978-605-82433-3-0.

Terziev, V., Petkov, M., Krastev, D. (2018t). The „Source of law“ category. // Proceedings of SOCIOINT 2018- 5th International Conference on Education, Social Sciences and Humanities, 2-4 July 2018Dubai, U.A.E, International Organization Center of Academic Research, www.ocerints.org, pp.517521, ISBN: 978-605-82433-3-0.

Petkov, Marin. (2018y). The national security system. // XIX International Scientific Conference Knowledge in practice (14 - 16 december, 2018, Bansko, Bulgaria), International journal scientific papers, IKM Skopje, Macedonia, 28, 2018, 6, pp. 1849-1854, ISSN 1857- 923X (for e-version), ISSN 2545 - 4439 (for printed version). 